\title{
Police Officer Transformational Leadership: Development and Validation of a Self-reported Scale
}

\author{
Marc Dussault ${ }^{1}$, Andrée-Ann Deschênes ${ }^{2}$, Éric Frenette ${ }^{3}$ \\ ${ }^{1}$ Business School, University of Québec in Trois-Rivières, Trois-Rivières, Canada \\ ${ }^{2}$ Department of Administrative Sciences, University of Québec in Rimouski, Rimouski, Canada \\ ${ }^{3}$ Faculty of Education, Laval University, Québec, Canada
}

Email address:

Marc.Dussault@uqtr.ca (M. Dussault)

\section{To cite this article:}

Marc Dussault, Andrée-Ann Deschênes, Éric Frenette. Police Officer Transformational Leadership: Development and Validation of a Selfreported Scale. American Journal of Applied Psychology. Vol. 7, No. 6, 2018, pp. 67-72. doi: 10.11648/j.ajap.20180706.11

Received: January 3, 2019; Accepted: January 25, 2019; Published: February 20, 2019

\begin{abstract}
The aim of this study is to develop and test the factorial validity of a questionnaire about police officer's transformational leadership on the ground. Based on Bass's (1985) transactional/transformational leadership model, Police Officers Transformational Leadership Scale is composed of 33 items rated on a Likert-type scale from (1) Completely disagree to (6) Completely agree. Respondents were 167 police officers from a large French Canadian police organization and two small police corps. The results show that a model structure with two second-order dimensions (transactional and transformational leadership), consistent with Bass's theory (1985), provided a good fit to the data. The results suggest that this questionnaire is well suited for describing the transformational leadership of police officers.
\end{abstract}

Keywords: Police Officer, Transformational Leadership, Self-reported Scale

\section{Introduction}

Policing has changed over the last 30 years. It has changed from a reactive military model to a more proactive model of community policing [1]. In such a model, police aim at problem solving instead of crime elucidation and are more concerned with citizens' specific problems and concerns [2]. Community policing is modifying police officers' work. Police officers become more autonomous at work. They must improve their relationships with citizens [3], and collaborate with the community to improve quality of life and feelings of safety [4]. Moreover, police officers must become effective communicators [5]. They must be engaged in their community, listen carefully to citizens and seek citizens' involvement whenever possible. Police officers must make fundamental decisions on the street, far from their supervisors [4]. According to Bayley [6] and Shearing (1996), community policing transforms police from being an emergency squad in the fight against crime to becoming primary diagnosticians and treatment coordinators. In the bigger picture, community police officers' work includes resolving conflicts, helping victims, preventing accidents, solving problems, and reducing fear as well as reducing crime [7, 8]. These behaviors call for police officers' leadership.

However, when it comes to assess police officers' leadership, there is no measurement instrument to our knowledge. Previous studies about police leadership were interest in the leadership of police chiefs [9], and police managers $[10,11,12,5,13]$. Therefore, the aim of the study reported herein is to develop and validate a measurement instrument of police officer leadership in their practice on the ground.

\section{Theoretical Framework}

Over the past three decades, new leadership theories have occupied a central position in leadership studies. These theories refer to authentic leadership [14], charismatic leadership [15] (Conger, \& Kanungo, 1994), relational leadership [16] (Uhl-Bien, 2006), servant leadership [17] (Parris, \& Peachey, 2013), shared leadership [18] (Pearce, Conger, \& Locke, 2008), transformational leadership [19] (Bass, 1985), and visionary leadership [20, 21, 22] (Saskin, 1988; Nanus, 1992; Posner and Kouzes, 1993). The study 
adopted Bass's transformational model of leadership (1985) because it is the most widely used. Moreover, it has been validated in various fields such as the military [23] (Kane \& Tremble, 2000), education [24, 25] (Koh, Steers, \& Terborg, 1995; Dussault, Payette, \& Leroux, 2008), project management [26] (Thite, 2000), and coaching [27] (Rowold, 2006). According to [28] Vito, Higgins, and, Denney (2014), the transactional/transformational leadership applies well to police leadership. Moreover, [29] Andreescu and Vito (2010) show that police officers tend to favour a transformational leadership style for their managers. This theory describes leadership according to three dimensions: transactional, transformational, and laissez-faire [30] (Avolio, Bass, \& Jung, 1999). Most effective leaders use both transactional and transformational leadership style [30, 31] (Avolio, et al., 1999; Bass, 1997) and avoid laissez-faire, which is nonleadership.

Transactional leadership involves day-to-day management and close contact. This leadership style is composed of two factors: contingent reward and management-by-exception. Leaders using contingent reward reinforce positively subordinates when they do what is required. Managementby-exception is the use of negative feedback if subordinates fail to meet expectations. The leader neglects to provide instructions when subordinates met their objectives, he allows subordinates to continue to do work as usual as long as they meet performance goals. He intervenes only when problems arise.

Transformational leadership is comprised of three factors: charisma, intellectual stimulation, and individualized consideration. Charismatic leaders are highly esteemed, they are role models that followers strive to emulate and align around a common mission [32] (Bass, Avolio, \& Atwater, 1996). Such leaders create loyalty and enthusiasm in subordinates. Intellectual stimulating leaders encourage subordinates to think outside of the box, to innovate, to be aware of the problems and reflect on solutions. Leaders paying attention to the needs and skills of their subordinates use individualized consideration. They do so in supporting subordinates through some form of coaching.

Finally, the last dimension of Bass's model is the laissezfaire leadership. It is a non-leadership style because the leader refuses to make decision, avoid conflicts, and is not available when subordinates need him [30] (Avolio, et al., 1999). Considering the nature of police officer jobs that calls for actions, and previous studies in policing [10, 11, 13, 4] (Deluga \& Souza, 1991; Espinoza-Parra, et al., 2015; Shim, et al., 2015; Steinheider, \& Wuestewald, 2008), and military [33, 34, 35] (Atwater \& Yammarino, 1993; Hardy et al., 2010, Ivey, \& Kline, 2010) that do not take into account laissez-faire, it was decided that laissez-faire would not be assessed in the questionnaire.

When measuring leadership, the instrument must have good psychometric properties (reliability and factorial validity) for intended use [36] (Crocker \& Algina, 1986). Moreover, it should be of a minimum length that will yield score with good psychometric properties. It is also important to mention that except [5] McLeod and Herrington (2016), no studies have presented a police leadership questionnaire nor a self-version of a police leadership questionnaire based on Bass theoretical framework. With the advent of new assessment methods (i.e. 360-degree feedback), a self-report instrument to assess police officer leadership appears justified. This type of instrument would enable police officer to assess their self-awareness by comparing their perceptions to those of their colleagues, and superiors.

\section{Method}

\subsection{Item Construction}

Interviews were performed with two police officers who are sergeants in two French Canadian police corps and an executive from the École Nationale de Police du Québec (Québec National Police School). The interviews aims at describing police officers leadership behaviors according to the multifactor leadership model. During the interview, each factor of the multifactor leadership model was described first. Next, there were ask if they knew police officers who are performing such behaviors. After, they were ask to describe the behaviors performed by these officers. At the highlight of these interviews and inspired by scales such as Multifactor leadership Questionnaire [30] (Avolio et al., 1999), Échelle $\mathrm{du}$ leadership transformatif $\mathrm{du}$ directeur d'école (Transformational leadership scale for school principal) [37] (Dussault, Valois, \& Fernette, 2007), Transformational leadership Inventory [38] (Podsakoff. MacKenzie, \& Bommer, 1996) the Police Officer Transformational Leadership Scale was done.

The Police Officer Transformational Leadership Scale is composed of 33 items rated on a Likert-type scale from (1) Completely disagree to (6) Completely agree. As suggested by [39] Laveault and Grégoire (1997) and [40] McDonald (1999), a neutral option was not used because it is problematic and it does not necessarily represent a strictly neutral position. Transactional leadership is assessed with 11 items; seven items for contingent rewards (i.e. I thank a citizen for his help), and four items for management-byexception (i.e. I tell a cyclist that he is riding dangerously). Transformational leadership is assessed with 22 items; nine for charisma (i.e. I am passionate by my work), seven items for individual consideration (i.e. I am having a coffee with citizens at the coffee shop), and six items for intellectual stimulation (i.e. I share information with colleagues).

\subsection{Sample}

Following the signing of a confidentiality agreement with the targeted organizations, the invitation to respond to the questionnaire was initiated through the police. The diffusion of this one was done by the professional e-mail. A text presenting the objective of the study was presented in the email in addition to the web link to complete the electronic questionnaire.

Respondents were 167 police officers from a large French 
Canadian police organization and two small police corps. They are 31 females and 129 males (seven do not indicate their gender). Eight were aged between 18-24 years old; 38 between 25-34 years old; 45 between 35-44 years old; 69 between 45-54 years old, and 7 were older than 55 years old. They have between one year of experience as police officer and more than 36 years of experience. Twenty-six have less than a year of experience as police officer, 27 have between 1 and 5 year of experience, 24 have between 6 and 10 years of experience, 30 have between 11 and 15 years of experience, 15 have between 16 and 20 years, 13 have between 21 and 25 years of experience, 15 have between 26 and 30 years of experience, one between 31 and 35 years of experience, and six have more than 36 years of experience (10 do not indicate their experience as police officer).

\subsection{Analyses}

First descriptive analyses (items, factors and dimensions) are presented, follow by internal consistencies and correlations (factors and dimensions). Second, confirmatory analysis is performed to verify the factorial structure of the questionnaire.

The tested model is based on [19] Bass' (1985) theory of leadership and previous studies [41, 42] (Bycio, Hackett, \& Allen, 1995; Waldman, Bass, \& Einstein, 1987) which propose a structure with two second-order dimensions (transactional and transformational leadership). Three factors (charisma, individualized consideration, and intellectual stimulation) are associated with the first second-order dimension (transformational leadership) and two factors (contingent reward and management-by-exception) are associated with the second second-order dimension (transactional leadership).

The factor structure was tested with confirmatory factor analysis using EQS6.2 [43] (Bentler, 1990). Maximum likelihood estimation is used. Three indices were used to estimate the correspondence between the matrices of theoretical and empirical estimates: the chi-squared statistic $(\chi 2)$, the comparative fit index (CFI), and the non-normed fit index (NNFI) proposed by [44] Tucker and Lewis (1973). A non-significant $\chi 2$ therefore indicates that the proposed model adequately represents the sample date. However, the $\chi 2$ statistic is very sensitive to sample size, tending to increase significantly with increasing sample size [45] (Marsh, Balla, \& McDonald, 1988). Therefore, it is strongly recommended to use other indices such as the $\chi^{2 / \mathrm{df}}$, CFI and the NNFI [43] (Bentler, 1990). A $\chi 2 / \mathrm{df}$ value close to 2 indicates goods fit to the data, whereas a value close to 5 indicates an adequate fit. Models that present CFI and NNFI above .90 are generally considered adequate [45] (Schumacker \& Lomax, 1996), while models presenting values above .95 are considered to provide a good fit [46] (Hu \& Bentler, 1999).

Based on a small sample size and the number of parameters to estimate in the model, item parcels (mean score for each factor) based on different recommandations [47, 48] (Little, Rhemtulla, Gibson, \& Schoemann, 2013; Marsh,
Lüdtke, Nagengast Morin \& Von Davier, 2013) were used instead of items.

\section{Results}

Table 1 presents means score for each of the item of the questionnaire. It shows that items related to contingent reward have the highest mean score. Moreover, it also shows that items related to individual consideration and to management-by-exception obtained the lower mean score.

Table 1. Means score for each item of the scale.

\begin{tabular}{ll}
\hline Item & M (SD) \\
\hline Transformational leadership & \\
Charisma & \\
I smile in public. & $4.9(1.1)$ \\
I communicate enthusiastically with citizens. & $5.1(0.8)$ \\
I'm honest with my colleagues. & $5.2(0.8)$ \\
I get involved with my community. & $3.9(1.5)$ \\
I listen carefully when talking with citizens. & $5.1(0.9)$ \\
I'm passionate about my work. & $4.9(1.2)$ \\
I look at problems with optimism. & $4.7(1.0)$ \\
I express myself positively with citizens. & $5.3(0.7)$ \\
Intellectual stimulation & \\
I point out careless cycling behaviour. & $3.9(1.4)$ \\
I challenge my colleagues to improve their services. & $4.1(1.4)$ \\
I share information with citizens. & $4.1(1.3)$ \\
I share the information with my colleagues. & $5.3(0.7)$ \\
I seek citizen involvement whenever possible. & $4.1(1.1)$ \\
I inform citizens of certain problems. & $4.6(0.9)$ \\
Personal recognition & \\
I recognize the citizens in my territory (neighbourhood). & $4.4(1.3)$ \\
I have coffee with citizens at the local restaurant. & $3.0(1.7)$ \\
I take interest in the lives of citizens. & $4.5(1.1)$ \\
I take interest in those who have recently be victimized by a & $5.1(0.9)$ \\
crime. & $5.1(0.7)$ \\
I recognize potential in each person. & $5.1(1.0)$ \\
At the restaurant, I say hello to citizens. & $3.8(1.6)$ \\
I talk with street workers. & \\
Transactional leadership & \\
Contingent reward & $5.4(.74)$ \\
I congratulate colleagues on their successes. & $4.9(1.1)$ \\
During briefings, I point out the good performance of & $5.3(0.8)$ \\
colleagues. & $5.5(0.7)$ \\
I recognize the good performance of colleagues. & $4.9(1.1)$ \\
I thank citizens for their assistance. & $4.4(1.3)$ \\
I congratulate citizens on their good behaviour. & $5.2(0.9)$ \\
I submit the candidacy of a colleague for a job well done. & \\
I thank citizens for their civic actions. & $4.5(1.2)$ \\
Management-by-exception & $3.9(1.4)$ \\
I remind colleagues when they neglect guidelines. & $5.2(0.7)$ \\
I point out careless cycling behaviour. & $4.5(1.1)$ \\
\hline If a colleague experiences difficulties at work, I help bring \\
corrective measures.
\end{tabular}

Table 2 shows that the scale presents good internal consistency $(\alpha=.88)$. Transactional leadership has good internal consistency $(\alpha=.83)$, as for contingent reward $(\alpha=.81) \quad$ and management-by-exception $(\alpha=70)$. Transformational leadership also presents good internal consistency $(\alpha=.88)$ as for charisma $(\alpha=.75)$, intellectual stimulation $(\alpha=.77)$, and individual consideration $(\alpha=.78)$. 
Table 2 also presents means score for each factor. It shows that participants perceived themselves as more transactional leader than transformational even though scores are high on both scales. A surprising result, considering that according to [29] Andreescu and Vito (2010), police officers favour a transformational leadership style for their managers. Moreover, it shows that contingent reward obtain the higher score of all subscales. Table 2 shows moderate positive significant correlations between all dimensions and subscales.

Table 2. Intercorrelation matrix between variables.

\begin{tabular}{|c|c|c|c|c|c|c|c|c|}
\hline Variable & M (SD) & $\alpha$ & 2 & 3 & 4 & 5 & 6 & 7 \\
\hline 1) Transactional & $4.8(.63)$ & .83 & .84 & .90 & .90 & .73 & .73 & .61 \\
\hline 2) Contigent Reward & $5.1(.65)$ & .81 & & .53 & .67 & .62 & .63 & .54 \\
\hline 3) Management-by-exception & $4.4(.80)$ & .70 & & & .61 & .44 & .64 & .53 \\
\hline 4) Transformational & $4.6(.63)$ & .88 & & & & .86 & .90 & .89 \\
\hline 5) Charisma & $4.9(.62)$ & .75 & & & & & .70 & .62 \\
\hline 6) Intellectual Stimulation & $4.5(.74)$ & .77 & & & & & & .69 \\
\hline 7) Individual consideration & $4.4(.79)$ & .75 & & & & & & \\
\hline
\end{tabular}

All correlations are significant at .01 level

Figure 1 presents the standardized solution to the confirmatory factor analysis for police officers. The indices for the tested model with a structure that includes two second-order dimensions (transactional leadership and transformational leadership) presents a good fit to the data $\left(\chi^{2}=11.27, \mathrm{df}=4 ; \chi^{2} / \mathrm{df}=2.8 ; \mathrm{NNFI}=.96 ; \mathrm{CFI}=.98\right)$ for police officers. Each loading of the model is significant. The Figure 1 shows that Contingent reward and Management-byexception contribute equivalently to transactional leadership. Moreover, it shows that Individual consideration has a higher contribution to transformational leadership than Charisma and Intellectual stimulation.

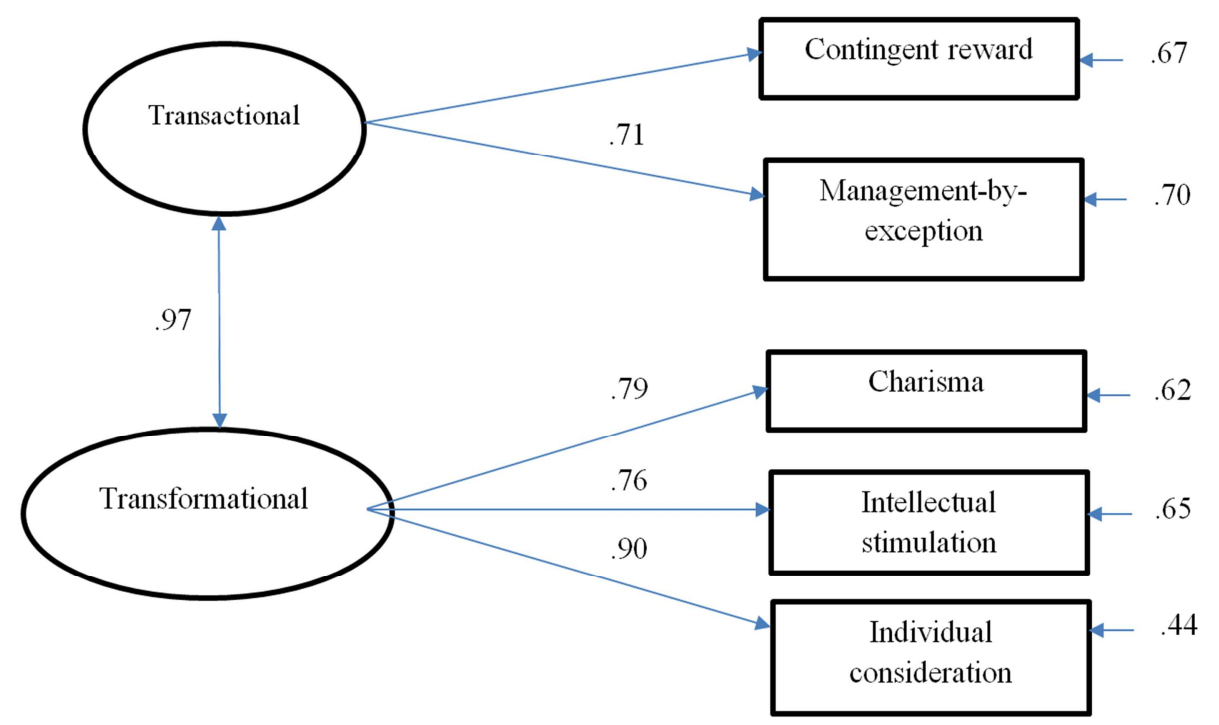

Figure 1. Standardized solution to the confirmatory factor analysis for police officers.

\section{Discussion}

The objective of this study was to develop and validate a self-report instrument to measure police officer leadership on the ground according to the Bass's transformational/transactional leadership paradigm. The results show that a model structure with two second-order dimensions (transactional and transformational leadership), consistent with [19] Bass's theory (1985), provided a good fit to the data.

From a scientific standpoint, the Police Officer Transformational Leadership Scale, with its good psychometric properties, could contribute to an empirical description of perceived police officer leadership. On the practical side, police officers could compare their own perceptions with those of their chief, manager, or colleagues in a 360-degree assessment. This would help police officers become more aware of their behaviors. It would also encourage police officers to take leadership training that would target their shortcomings. Moreover, the questionnaire could be used to verify the effect of leadership training on police officers' perceptions of their own leadership. Future studies can use this scale to try to identify predictors of police officer leadership. These studies could link leadership to variables such as motivation, commitment and personality, for example. Other studies could explore the relationship between police officer leadership and outcomes like criminality or citizens' feelings of safety.

Certain limitations of this study should be addressed in future research. The small sample comprises police officers working in three police corps so the psychometric properties of the questionnaire should be verified in other police officers 
populations and larger samples. Future studies could also verify the predictive validity of this instrument. Follow-ups could also be performed on cohorts of police officers programs to determine the impact on self-perceptions of leadership.

\section{Conclusion}

The study presents the validation of a questionnaire to assess leadership of police officers. Based on [19] Bass's (1985) multifactor leadership theory, the scale is composed of 33 items rated on a 6-point Likert-type scale. The questionnaire assesses transactional leadership (Contingent reward and Management-by-exception) and transformational leadership (charisma, intellectual stimulation and personal recognition). It does not take into account laissez-faire leadership because the nature of police officer jobs calls for actions. Respondents were 167 French Canadian police officers. The results show that the questionnaire has good psychometric properties and can be use in future studies.

\section{References}

[1] Brien, P. (2005, mai). Bilan de la police au Québec de 1990 à 2005: Perspective d'un praticien. Historique et bilan en matière de police communautaire au Québec, Montréal: Université de Montréal.

[2] Brodeur, J. P. (2003). Les visages de la police: Pratiques et perceptions. Montréal: Les Presses de l'Université de Montréal.

[3] Stronks, S. (2015). Community police officers and selfinvolved conflict: An explorative study on reconciliation with citizens. Policing: A Journal of Policy and Practice, 10 (3), 206-221.

[4] Steinheider, B., \& Wuestewald, T. (2008). From the botton-up: sharing leadership in a police agency. Police Practice and Research, 9 (2) 145-163.

[5] McLeod, A., \& Herrington, V. (2016). Fostering police leadership capacity in Solomon Islands: Understanding the challenges to organizational reform. Policing: A Journal of Policy and Practice, 10 (1). 44-54.

[6] Bayley, D. H. \& Shearing, C. D. (1996). The future of policing. Law \& Society Review, 30 (3), 585-606.

[7] Cordner, G. (2014). Community policing. In M. D. Reisig \& R. J. Kane (Eds), The Oxford handbook of police and policing (pp 148-171). Oxford, UK: Oxford Handbooks.

[8] Vinzant, J. \& Crothers, L. (1994). Street-level leadership: The role of patrol officers in community policing. Criminal Justice Review, 19 (2), 189-211.

[9] Sarver, M. B., \& Miller, H. (2014). Police chief leadership: styles and effectiveness. Policing: An international Journal of Police Strategies \& Management, 37 (1), 126-143.

[10] Deluga, R. J., \& Souza, J. (1991). The effects of transformational and transactional leadership styles on the inflencing behaviour of subordinate police officers. Journal of Occupational Psychology, 64, 49-55.
[11] Espinoza-Parra, S., Molero, F., \& Fuster-Ruizdeapodaca, M. J. (2015). Transformational leadership and job satisfaction of police officers (carabineros) in Chile: The mediating effects of group identification and work engagement. Revista de Psicologia Social/International Journal of Social Psychology, 30 (3), 439-467.

[12] Huberts, L. W. J. C., Kaptein, M., \& Lasthuizen, K. (2007). A study of the impact of three leadership styles on integrity violations committed by police officers. Policing: An international Journal of Police Strategies \& Management, 30 (4), 587-607.

[13] Shim, H. S., Jo, Y., Hoover, L. T. (2015). Police transformational leadership and organizational commitment: Mediating role of organizational culture. Policing: An international Journal of Police Strategies \& Management, 38 (4), 754-774.

[14] Walumba, F., Avolio, B., Gardner, W., Wernsing, T., \& Peterson, S. (2008). Authentic leadership: Development and validation of a theory-based measure. Journal of Management, 34 (1), 89-126.

[15] Conger, J. A., \& Kanungo, R. N. (1994) Charismatic leadership in organizations: perceived behavioural attributes and their measurement. Journal of Organizational Behaviour, $15,439-452$.

[16] Uhl-Bien, M. (2006). Relational leadership theory: Exploring the social processes of leadership and organizing. The Leadership Quarterly, 17, 654-676.

[17] Parris, D. L., \& Peachey, J. W. (2012). A systematic literature review of servant leadership theory in organizational contexts. Journal of Business Ethics, 113, 377-393.

[18] Pearce, C. L., Conger, J. A., \& Locke, E. A. (2008). Shared leadership theory. The Leadership Quarterly, 19, 622-628.

[19] Bass, B. M. (1985). Leadership and performance beyond expectations. New York: Free Press.

[20] Saskin, M. (1988). The visionary principal: school leadership for the next century. Education and Urban Society, 20, 239249 .

[21] Nanus, B. (1992). Visionary leadership. San Francisco, CA: Jossey-Bass.

[22] Posner, B. Z., \& Kouzes, J. M. (1993). Psychometric properties of the Leadership Practices Inventory- Updated. Educational and Psychological Measurement, 53, 191.199.

[23] Kane, T. D., \& Tremble, T. R. (2000). Transformational leadership effects of different levels of the Army. Military Psychology, 12 (2), 137-160.

[24] Koh, W. L., Steers, R. M., \& Terborg, J. R. (1995). The effects of transformational leadership on teacher attitudes and student performance in Singapore. Journal of Organizational Behaviour, 16, 319-333.

[25] Dussault, M., Payette, D., \& Leroux, M. (2008). Principals' Transformational leadership and teachers' collective efficacy. Psychological Report, 102, 401-410.

[26] Thite, M. (2000). Leadership styles in information technology projects. International Journal of Project Management, 18, 235-241. 
[27] Rowold, J. (2006) Transformational and transactional leadership in martial arts. Journal of Applied Sport Psychology, $18 \quad$ (4), 312-325. $\quad$ DOI: $10.1080 / 10413200600944082$.

[28] Vito, G. F., Higgins, G. E., \& Denney, A. S. (2014). Transactional and transformational leadership: An examination of the leadership challenge model. Policing: An International Journal of Police Strategies \& Management, 37 (4), 809-822. DOI 10.1108/PIJPSM-01-2014-0008.

[29] Andreescu, V., \& Vito, G. F. (2010). An Exploratory Study on Ideal Leadership Behaviour: The Opinions of American Police Managers. International Journal of Police Science \& Management, 12 (4), pp. 567-583.

[30] Avolio, B. J., Bass, B. M., \& Jung, D. I. (1999). Re-examining the components of transformational and transactional leadership using the Multifactor Leadership Questionnaire. Journal of Occupational and Organizational Psychology, 72, 441-462.

[31] Bass, B. M. (1997). Does the transactional-transformational leadership paradigm transcend organizational and national boundaries? American Psychologist, 52 (2), 130-139.

[32] Bass, B. M., Avolio, B. J., \& Atwater, L. (1996). The transformational and transactional leadership of men and women. Applied Psychology: an International Review, 45 (1), $5-34$.

[33] Atwater, L. E., \& Yammarino, F. J. (1993). Personal attributes as predictors of superiors' and subordinates' perceptions of military academy leadership. Human Relations, 46 (5), 645668.

[34] Hardy, L., Arthur, C. A., Jones, G., Shariff, A., Munnoch, K., Isaacs, I., \& Allsopp, A. (2010). The relationship between transformational leadership behaviors, psychological, and training outcomes in elite military recruits. The Leadership Quarterly, 21, 20-32.

[35] Ivey, G. W., \& Kline, J. B. (2010). Transformational and active transactional leadership in the Canadian Military. Leadership \& Organization Development Journal, 31 (3), 246-262.

[36] Crocker, L., \& Algina, J. (1986) Introduction to classical and modern test theory. New York: Harcourt Brace Jovanovich College Publishers.
[37] Dussault, M., Valois, P., \& Frenette, É. (2007). Validation de l'échelle de Leadership Transformatif du directeur d'école. Psychologie du Travail et des Organisations, 13 (2), 37-52.

[38] Podsakoff, P. M., MacKenzie, S. B., \& Bommer, W. H. (1996). Transformational leader behaviors and subtitutes for leadership as determinants of employee satisfaction, commitment, trust, and organizational citizenship behaviors. Journal of Management, 22 (2), 259-298.

[39] Laveault, D., \& Grégoire, J. (1997) Introduction aux théories des tests en sciences humaines [Introduction to testing theories in human sciences]. Paris, Bruxelles: De-Boeck université.

[40] McDonald, R. P. (1999) Test theory: a unified treatment. Mahwah, NJ: Lawrence Erlbaum Associates, Inc.

[41] Bycio, P., Hackett, R. D., \& Allen, J. S. (1995). Further assessments of Bass's (1985) conceptualization of transactional and transformational leadership. Journal of Applied Psychology, 80 (4), 468-478.

[42] Waldman, D. A., Bass, B. M., \& Einstein, W. O. (1987). Leadership and outcomes of performance appraisal processes. Journal of Occupational and Organizational Psychology, 60 (3), 177-186.

[43] Bentler, P. M. (2006). EQS structural equations program manual. Encino, CA: Multivariate Software, Inc.

[44] Tucker, L. R., \& Lewis, C. (1973). A reliability coefficient for maximum likelihood factor analysis. Psychometrika, 38, 1-10.

[45] Schumacker, R. E., \& Lomax, R. G. (1996) A beginner's guide to structural equation modeling. Mahwah, NJ: Lawrence Erlbaum Associates.

[46] Hu, L. T., Bentler, P. (1999). Cutoff criteria for fit indexes on covariance structure analysis: Conventional criteria versus new alternatives. Structure Equation Modeling: A multidisciplinary Journal, 6 (1), 1-55.

[47] Little, T. D., Rhemtulla, M., Gibson, K., Schoemann, A. M. (2013). Why items versus parcels controversy needn't be one? Psychological Reports, 18 (3), 285-300.

[48] Marsh, H. W., Lüdtke, O., Nagengast, B., Morin, A. J. S., \& Von Davier, M. (2013). Why items parcels are (almost) never appropriate: two wrongs do not make a right-Camouflage misspecification with item parcels in CFA models. Psychological Methods, 18 (2), 257-284. 